\title{
ALOKASI PENDAPATAN DAN LITERASI KEUANGAN Studi Kasus pada Desa Sidomukti Kecamatan Plaosan Kabupaten Magetan
}

\author{
Nurul Hidayah, SE, M. Ak. \\ Universitas Muhammadiyah Ponorogo \\ Hidayahnurul898@gmail.com
}

\begin{abstract}
This study aims to determine the allocation of income and financial understanding to working housewives and housewives who do not work in the Village Sidomukti Plaosan District Magetan. This study used a survey method conducted to 80 respondents consisting of 40 housewives who do not work and 40 housewives who work. This research uses descriptive and explanative research method. This research is done by collecting data to describe and give more detailed explanation about phenomenon of research subject then explain the relationship between phenomena. The results of this study illustrate that there is no significant difference between housewives who do not work and work in the allocation of income. While the level of financial literacy with high categories more owned by working housewives. In addition, the relationship between the level of financial literacy with the allocation of income between both types of housewives has opposite results. Housewives who do not work with high levels of financial literacy are more efficient in allocating their income while for working mothers get the opposite.
\end{abstract}

Keywords: Housewife, income allocation, financial literacy

\section{PENDAHULUAN}

Setiap manusia memiliki tujuan hidup yang yang ingin dicapai. Tujuan akan berbeda pada setiap individu, tetapi pada umumnya setiap keluarga memiliki tujuan yang sama yaitu kebahagiaan di dunia dan di akhirat. Manusia akan hidup sukses jika apa yang diinginkan tercapai. Kebahagiaan dunia akan bisa diukur dengan berbagai hal misalkan harta yang berlimpah, karier yang bagus dan juga kesuksesan anak. Disamping itu, bidang keuangan dikatakan sukses jika seseorang sudah mencapai masa kebebasan keuangan yaitu dimana uang sudah tidak lagi menjadi tujuan hidupnya. Budaya konsumerisme yang tinggi dalam masyarakat menyebabkan harga semua barang naik. Selain itu, budaya kepanikan akan ketersediaan barang juga akan menimbulkan kenaikan 
harga. Hal tersebut justru dapat mengganggu keuangan pada rumah tangga. Kebiasaan ini sangat sering dilakukan oleh ibu rumah tangga baik yang bekerja maupun yang tidak bekerja. Kecenderungan masyarakat kita yang konsumtif dan kurangnya minat menabung di masyarakat menyebabkan keuangan keluarga akan mengalami gangguan. Pengetahuan keuangan sangat diperlukan oleh para ibu rumah tangga karena ibarat sebuah perusahaan ibu rumah tangga adalah manajer keuangan.

Kepala divisi keuangan dan perlindungan konsumen OJK, Lamsaida s mengatakan bahwa ibu rumah tangga menjadi salah satu sasaran dalam sosialisasi dan edukasi produk keuangan karena kedudukan ibu rumah tangga sebagai pengatur pergerakan ekonomi keluarga salah satunya adalah pengelolaan keuangan (http://merdeka.com/). Era modern seperti sekarang ini sudah banyak ditemukan wanita yang berstatus tidak hanya sebagai ibu rumah tangga tetapi juga memiliki profesi sebagai wanita karier. Jadi ibu rumah tangga saat ini memiliki peran ganda yaitu peran sebagai wanita yang mengurus rumah tangga dan peran sebagai karyawan pada sebuah perusahaan. Peran ibu rumah tangga tidak hanya mengurus rumah tangga tetapi juga mencari nafkah bagi keluarga, sehingga seorang ibu rumah tangga memiliki pendapatan ganda yaitu dari suaminya dan dari hasil dia bekerja. Berbeda dengan seorang ibu rumah tangga yang tidak bekerja. Dia hanya mendapatkan pendapatan dari suaminya saja. Namun seiring perkembangan jaman, saat ini banyak sekali seorang ibu rumah tangga yang menjadi tulang punggung keluarga. Artinya dia sebagai penopang ekonomi keluarga.

Terdapat perbedaan jumlah pendapatan pada rumah tangga antara ibu rumah tangga yang bekerja dan yang tidak bekerja pada berbagai lapisan masyarakat. Setiap rumah tangga harus bisa mengalokasikaan pendapatan rumah tangganya dengan baik demi terpenuhinya semua kebutuhan rumah tangga keluarga. Kondisi seperti itu menunjukkan bahwa setiap rumah tangga memerlukan perencanaan keuangan yang baik sehingga dapat mengalokasikan pendapatan demi terpenuhinya kesejahteraan fiskal baik jangka pendek maupun jangka panjang. Perbedaan sumber pendapatan akan menyebabkan perbedaan 
pula dalam alokasi pendapatan. Ibu rumah tangga yang bekerja lebih leluasa menggunakan pendapatannya seperti untuk memenuhi kebutuhan gaya hidup teman seprofesi ataupun teman diluar itu. Hal inilah yang terkadang membuat pengeluaran lebih besar daripada pendapatan, maka dari itu diperlukanlah literasi dan perencanaan keuangan pada ibu rumah tangga yang bekerja.

Alokasi pendapatan yang berbeda menyebabkan perlunya perencanaan keuangan yang berbeda pada ibu brumah tangga yang bekerja maupun ibu rumah tangga yang tidak bekerja. Ibu rumah tangga yang bekerja seharusnya memiliki tingkat literasi keuangan yang lebih baik dibandingkan dengan ibu ruamh tangga yang tidak bekerja, karena ibu rumah tangga yang bekerja memiliki pengetahuan yang luas dan memiliki kompetensi yaang berbeda dengan ibu rumah tangga yang tidak bekerja. Melihat adanya perbedaan diatas kiranya perlu dilakukan penelitian mengenai alokasi pendapatan dan literasi keuangan pada ibu-ibu rumah tangga.

Penelitian ini mencoba mencari perbedaan alokasi pendapatan dan literasi keuangan pada ibu rumah tangga yang bekerja dan ibu rumah tangga yang tidak bekerja, sehingga rumusan masalah dari penelitian ini adalah:

1. Bagaimanakah pola alokasi pendapatan pada ibu rumah tangga yang bekerja dan ibu rumah tangga yang tidak bekerja?

2. Bagaimanakah literasi keuangan yang dimiliki oleh ibu rumah tangga yang bekerja dan yang tidak bekerja?

3. Bagaimanakah keterkaitan antara ibu rumah tangga yang bekerja dan ibu rumah tangga yang tidak bekerja berdasarkan alokasi pendapatan yang dilakukan dan tingkat literasi keuangan?

\section{TELAAH LITERATUR DAN PENGEMBANGAN HIPOTESIS}

\section{A. IBU RUMAH TANGGA YANG BEKERJA DAN IBU RUMAH TANGGA YANG TIDAK BEKERJA}

Keberadaan perempuan yang menyandang status sebagai ibu rumah tangga secara tradisi menurut tuti dan fadilah (2001:9) sebagaimana dikutip oleh naibaho (2009) berkewajiban untuk mengurus rumah tangga. Tugas ini 
mencakup menyediakan makan untuk anggota keluarga, mengurus dan manta rumah, mengasuh anak dan sebagainyayang terkait dengan upaya menumbuhkan kenyamanan dan keasrian rumah tangga. Namun setelah adanya emansipasi perempuan yang bertujuan memperjuangkan persamaan derajat antara perempuan dan laki - laki yang telah membawa perubahan yang besar pada peran perempuan di sector public. Perubahan tersebut menurut Sujarwa (2001:100) membawa konsekuensi yang bersifat psikologik (pribadi dan kemasyarakatan) dimana perempuan menjadi lebih percaya diri, tidak terlalu tergantung, lebih realistic dan memperlihatkan perannya sebagai pribadi individu. Sehingga, pada saat ini semakin banyak ibu rumah tangga yang memasuki dunia kerja atau berkarir.

Akan tetapi, seirung berjalannya waktu tidak dapat dipungkiri bahwa realitas sosial saat ini semakin sulit. Dimana penduduk Indonesia yang terus mengalami peningkatan sehingga peluang untuk memperoleh pekerjaan semakin sulit. Namun disisi lain, kebutuhan hidup terus mengalami peningkatan dan hal ini menjadikan banyak ibu rumah tangga yang tidak hanya mencari nafkah tambahan, tetapi juga menjadi penopang pokok ekonomi rumah tangga.

Ibu rumah tangga yang bekerja seperti ini dapat dikatakan bahwa memilki peran ganda dimana sebagai seoarang istri beliau memilki kewajiban untuk menguru rumah tangga, namun di satu sisi lainnya beliau harus terlibat dalam kegiatan ekonomi untuk mencari penghasilan tambahan (Munandar 1985:4-7). Seoarang perempuan dituntut untuk pandai dalam mengelola waktu dan aktivitasnya serta akibatnya dalam psikis dan fisiknya. Sehingga kesanggupan perempuan dalam berperan ganda merupakan pilihan yang berdasrkan kondisi objektif dan kematangan berpikir.

Hoffman (1984) dalam bukunya yang berjudul Working Mathers: An Evaluative Review Of The Consequences For Wife, Husband, And Child, menyebutkan beberapa faktor yang mempengaruhi keputusan seorang ibu untuk bekerja, diantaranya adalah:

1. Kebutuhan ekonomi. Terdapat banyak motif yang mendasari faktor ini 
yang tergantung dari kondisi dan keadaan keluarga. Penghasilan suami yang tidak mencukupi paling sering menjadi motif terbesar. Namun, ada motif lain seperti ibu menginginkan barang - barang yang berharga yang membutuhkan uang lebih untuk dapat membelinya, karena itulah ibu bekerja.

2. Pekerjaan rumah tangga (peran sebagai ibu rumah tangga) yang lama kelamaan menjadi tidak lagi memuaskan, membosankan, dan tidak lagi membutuhakan keterampilan. Apalagi ketika anak terkecil sudah mulai memasuki sekolah, sehingga sering ibu merasa tidak dibutuhkan lagi di rumah (Bimbaum, 1971).

3. Kepribadian, misalnya kebutuhan untuk berprestasi, dihargai karena status yang lebih tinggi, keinginan untuk dapat bermanfaat bagi lingkungan dan juga menggunakan potensi - potensi yang dimiliki.

\section{B. ALOKASI PENDAPATAN RUMAH TANGGA}

Setiap rumah tangga pasti menginginkan masa depan yanga sejahtera dan bahagia dan ssalah satu faktor pendukungnya adalah dalman hal kesuksesan finansial. Garman dan forgue (1997) mengatakan bahwa kesuksesan finansial dapat tercapai jika telah memenuhi lima tujuan keuangan yang diantaranya adalah memperoleh pendapatan dan kekayaan yang maksimum, melakukan konsumsi secara efisien, menemukan kepuasan hidup, mencapai keamanan finansial dan mengumpulkan kekayaan untuk dinikmati saat masa pension dan sebagian ditinggalkan sebagai warisan. Dalam mencapai kesuksesan finanasial tersebut, seorang ibu rumah tangga yang memegang peranan roda pergerakan keuangan rumah tangga tidak berarti harus hemat, melainkan harus mengerti jumlah yang pantas untuk setiap pos pengeluaran (Senduk, 2001). Perencanaan keuangan merupakan sebuah kunci utama dalam mengalokasikan pendpatan rumah tangga secara optimal (Putlia, 2009).

Setelah perencanaan keuangan dilaksanakan, tugas pengelolaan keuangan yang kedua adalah memanfaatkan atau mengalokasikan 
pendapatan berarti mengimplementasikan perencanaan keuangan yang telah dilakukan. Masassya (2004: 9 - 10) membagi alokasi pendapatan menjadi tiga hal pokok yang antara lain berupa konsumsi, tabungan atau saving dan investasi. Akan tetapi dalam praktek sehari - hari, pengalokasian pendapatan ini mempunyai seni pengelolaan sendiri yang berbeda - beda sesuai dengan kebiasaan, pengalaman ataupun pengetahuan.

Selain itu, sebuah hal perlu diingat bagi seorang ibu rumah tangga yang berperan sebagai pemegang roda pergerakan keuangan rumah tangga adalah faktor kedisiplinan dalam proses mengalokasikan pendapatan sesuai dengan perencanan keuangan yang telah dilakukan sebelumnya. Setelah semua hal tersebut dijalankan dengan baik, kesuksesan finansial dan tujuan hidup yang sejahtera dan bahagia tentu dapt tercapai (Dorimulu, 2003)

\section{KONSUMSI}

Masassya (2004: 9-10) mengatakan bahwa pengalokasian pendapatan rumah tangga tersebut termasuk pengeluaran biaya tetap (fixed cost) yang tidak bisa ditunda lagi, yaitu angsuran rumah, biaya listrik, air, telepon, biaya makan, minum dan rekreasi. Biaya konsumsi ini beragam, akan teteapi perlu dipatok atau ditentukan lazimnya biaya ini berkisar antara 40\%-50\%.

Sedangakan Sudarsono (2005) mendefinisikan konsumsi sebagai semua biaya yang dikeluarkan oleh rumh tangga untuk memenuhi semua kebutuhan hidupnya yang terdiri atas konsumsi untuk makanan sehari - hari seperti beras, lauk pauk, sayur - sayuran dan lain - lain, serta konsumsi untuk non makanan seperti pakain, perumahan, pendidikan, kesehatan, hiburan rekreasi, sosial, pajak.

Oleh karena sebagian besar pengeluaran untuk konsumsi menjadi unsur alokasi pendapatan yang paling diutamkan dalam proses perencanaan dan kedisiplinan ke dalam pos lainnya yaitu tabungan dan investasi. 


\section{TABUNGAN}

Pada dasarnya setiap individu memiliki ketidakpastian yaitu ketakutan akan masa depan kehidupan finansial dan tidak ada seorangpun yang mampu untuk mencegah kecelakaan, penderitaan dan kesukaran dalam mengejar keberuntungan dan nasib baik (Wibawa, 2003). Ditambah lagi dengan perekonomian Indonesia yang seslau dipenuhi dengan tingkat inflasi dan ketidalpastian. Sehingga setip individu yang sadr akan pentingnay perencanaa keuangan akan memikirkan motif untuk untuk berjaga - jaga yang dapat digunakan dalam kepentinagn yang mendesak. Salah satu alternatifnya adalah dengan memilki tabungan dimana tabungan sebdiri didefinisikan sebagai simpanan di bank yang dpat ditarik berdasarkannsyarat - syarat tertentu (Muda 2003: 37). Selain itu, keuntungan dari tabungan adalah memeperoleh bunga dan tingkat resikonya yang tergolong rendah. Tidak semua rumah tangga memilki pendapatan yang lebih untuk dialokasikan ke dalam tabungan, akan tetapi Rini (2006:140) menyarankan jumlah tabungan rumah tangga sebesar 20\% hingga 30\% dari pendapatan keseluruhan.

Masassya (2004: 9-10) secara lebih detail menjelaskan pengalokasian pada tabungan yang mana dapat dimasukkan sebagai simpanan/ tabungan tetap dan bisa dimaksudkan sebagai tabungan untuk berjaga - jaga yaitu mislanya ada keperluan ke dokter dan memberi sumbanagan. Tabungan ini juga perlu ditentukan dan pada umunya berkisar 25\% dimana 10\%-15\% digunakan sebagai motif berjaga - jagadan sisanya digunakan sebagai tabungan tetap.

\section{E. INVESTASI}

Dalam melakukan perencanaan keuangan, seorang ibu rumah tangga harus memilikinpandangan yang selalu ke depan baik jangka pendek maupun jangka panjang. Dan dalam jangka panjang, di masa depan setiap keluarga juga pasti menginginkan kehidupan yang sejahtera dan bahagia. 
Oleh sebab itu, dalam perencanaan keuangan perlu dipikirkan untuk mengalokasikan pendapatan ked lam produk - produk keuangan yang ditawarkan dalam jas keuanga dengan tujuan investasi yang memperoleh keuntungan di masa mendatang (Dhuwita: 2003). Selain itu, motif lain yang mendorong seorang ibu rumah tangga untuk melakukan investasi adalah baik individu baik suami ataupaun dirinya sendiri yang bekerja maupun yang tidak bekerja secara fisik akan selalu behadan dengan usia pensiunnya (Budianto: 2006).

Akan tetapi, biasanya invesatasi dilakukan oleh rumah tangga yanga memilki sejumlaha kebebasan pendapatan setelah dialokasikan untuk konsumsi. Karena investasi sendiri memiliki definisi sebagai penempatan sejumlah dana pada saat ini dengan harapan mengahsilakn keuntungan dimasa depan (Halim, 2005).

\section{F. LITERASI KEUANGAN}

Chen dan Volpe (1998) mengartikan literasi keuangan sebagai pengetahuan untuk mengelola keuangan dalam pengembilan keputusan keuangan. Definisi tesebut dapat dijabarkan kedalam 4 dimensi yaitu:

1. Manajemen keuangan pribadi (personal finance) merupakan proses perencanaan dan pengendalian keuangan dari unit individu atau keluarga.

2. Bentuk simpanan di Bank yangdapat dilakukan dalam bentuk tabungan (sebagian pendapatan masyarakat yang tidak dibelanjakan disimpan sebagai cadangan guna berjaga - jaga dalam jangka pendek), deposito berjangka (simpanan pada Bank yang penarikannya hanya dapat dilakukan dalam jangka waktu tertentu), setifikat deposito (deposito berjangka yang bukti simpanannya dapat diperdagangkan) dan giro (Simpanan pada Bank yang dapat digunakan sebagai alat pembayaran).

3. Asuransi adalah salah satu bentuk pengendalian resiko yang dilakukan dengan cara mengalihkan/ transfer risiko dari satu pihak ke pihak lain (dalm hal ini adalah perusahaan asuransi). Pengertian asuransi yang lain adalah merupakan suatu pelimpahan resiko dari pihak pertama kepada 
pihaklain.

4. Investasi merupakan suatau bentuk pengalokasian pendapatan yang dilakukan saat ini untuk memperoleh manfaat keuntungan (return) di kemudian hari yang bisa melebihi modal investasi yang dikeluarkan saat ini.

\section{G. ALOKASI PENDAPATAN IBU RUMAH TANGGA YANG BEKERJA DAN TIDAK BEKERJA}

Fenomena ibu rumah tangga yang memegang roda pergerakan keuangan keluarganya menuntut para ibu rumah tangga untuk pandai dalam mengalokasikan pendapatan yang dimilikinya bai yang bersumber dari pendaatan suami saja, yang bersumber dari hasil bekerja ataupun gabungan pendapatannya dengan pendapatan suaminya dengan seoptimal mungkin. Menurut Wibawa (2003) faktor terpenting dalam mengalokasikan pendapatan adalah perencanaan keuangan. Karena secara sederhana perencanaan keuanagan keluarga berkaitan denganberpa banyak uang yang masuk dari pebdapatan dan berapa banyak uang yang keluar sebagai konsumsi dan berapa banyak uang yang dikeluarkan untuk ditabung dan diinvestasikan demi mencapai tujuan keluarga.

Akan tetapi bagi ibu rumah tangga yang bekerja diduga memiliki perilaku yang berbeda dalam mengalokasikan pendapatan rumah tangganya. Hal ini dikarenakan beliau merasa letih leluasa untuk mengalokasikan pendapatannya yang merupakan jerih payahnya sendiri. Kemudian semakin luas dan variatifnya pergaulan yang beliau jalani di dalam dunia kerja secara tidak langsung membuat beliau mengikuti gaya hidup mereka untuk dapat mengimbanginya. Sehingga seorang ibu rumah tangga yang bekerja ini akan menjadi cenderunng lebih konsumstif.

H. TINGKAT LITERASI KEUANGAN IBU RUMAH TANGGA YANG BEKERJA DAN IBU RUMAH TANGGA YANG TIDAK BEKERJA 
Dalam mengoptimalkan implementasi dari keuanga yang telah dibuat adalah dengan memilki literasi keuangan. Seseorang perlu memiliki pengetahuan, sikap dan implementasi keuanagan pribadi yang sehat yang dikenal dengan litersi keuangan (Widyawati, 2012). Terkait dengan investasi, hasil penelitian Sina dan Nggili (2012) yang juag mengatakan bhawa perempuan lebih peduli pada ketidakpastian pendapatan di masa dating, sehingga lebih berusaha untuk mencari tahu arti dan tujuan investasi. Dapat dikatakan literasi keuangan mengenai investasi yang dimiliki perempuan lebih tinggi dari pada laki - laki, sehingga perempuan mampu memahami resiko dan imbal hasil dalam melipatgandakan uang selain dengan menabung. Sehingga tidak mengherankan jika sebagian besar ibu rumah tangga yang memegang roda pergerakan keuangan keluarganya.

Namun dengan perbedaan status ibu rumah tangga yang tidak bekerja dan bekerja diduga memilki perbedaan tingkat literasi yang dimilikinya. Dimana seorang ibu rumah tangga yang bekerja biasanya memiliki tingkat literasi keuangan yang lebih tinggi dibandingkan ibu rumah tangga yang tidak bekerja. Hal tersebut dikarenkan keberadaannya dalam dunia kerja yang menjadikan pola pikirnya lebih terbuka dan memiliki wawasan yang luas dan dinamis dengan semakin banyak beliau bergaul dalam ruang lingkup yang semakin luas lebih banyak variasi pergaulannya.

\section{KETERKAITAN IBU RUMAH TANGGA YANG BEKERJA DAN} TIDAK BEKERJA DENGAN TINGKAT LITERASI KEUANGAN DAN ALOKASI PENDAPATAN

Literasi keuangan sehingga menjadi sesuatu yang dibutuhkan dalam kehidupan di era globalisasi ini agar dapat mengelola keuangan dengan baik dan mencapai kesejahteraan. Seorang ibu tumah tangga yang disertai dengan literasi keuangan yang tinggi dalam pengelolaan keuangannya tentu saja akan lebih berhati - hati dan lebih terencana dengan baik. Hal ini dibuktikan dalam hasil penelitian yang dilakukan oleh Navickas, dkk (2014) yang mengatakan bahwa literasi keuangan memiliki pengaruh yang sangat tinggi dalam 
manajemen keuangan pribadi baik dalam populasi Lithuanian, OECD, maupun di USA. Hal itu terlihat pada ibu rumah tangga yang berusia 18 tahun hingga 30 tahun tidakmmengerti dasar literasi keuangan, seperti bunga sederhana dan gabungan. Sehingga hal tersebut berdampak pada keputusan yang diambil dalam memilih pinjaman, pegadaian, deposito, ataupun produk keuangan lainnya.

Sebaliknya dalam hasil penelitian oleh Byrne (2007) mengatakan bahwa pengetahuan keuangan yang rendah akan menyebabkan pembuatan rencana keuangan yang salah dan menyebabakan bias dalam pencapaian kesejahteraan di saat usia tidak produktif lagi. Hal ini sejalan dengan penelitian yang dilakukan oleh Sina (2012) yang mengatakan bahwa rendahnya literasi keuangan berdampak pada kesejahteraan. Prioritas untuk meningkatkan literasi keuangan menjadi suatu keharusan bagi individu ataupun keluarga yang ingin sejahtera. Sehingga dalam penelitian ini dapat melihat keterkaitan ibu rumah tangga yang bekerja dan ibu rumah tangga yang tidak bekerja berdasrkan tingkat literasi keuangan dan alokasi pendapatan.

\section{METODE PENELITIAN dan PEMBAHASAN}

Penelitian yang dilakukan ini menggunkan metode penelitian deskriptif dan eksplanatif. Penelitian deskriptif merupakan penelitian yang melakukan pengumpulan data untuk menggambarkan dan memberi penjelasan yang lebih mendetail mengenai fenomena dari subjek penelitian. Sedangkan penelitian eksplanatif adalah penelitian yang menjelaskan hubungan antar fenomena.

Pengumpulan data untuk penelitian ini dilakukan melalui studi dokumentasi dengan mengumpulakan data pendukung, literature, jurnal dan buku buku referensi untuk mendapatkan gambaran masalah yang diteliti. Data pendukung diperoleh dengan menggunakan kuisioner tertutup dimana di dalam kuisioner tersebut telah disediakan semua alternatif jawaban yang telah mewakili variabel yang diteliti, sehingga responden hanya perlu memilih alternatif jawaban yang sesuai. 
Populasi dalam penelitian ini adalah ibu rumah tangga yang berada di Desa Sidomukti Kecamatan Plaosan Kabupaten Magetan baik yang bekerja maupun yang tidak bekerja. Pada penelitian ini metode pemilihan sampel yang digunakan merupakan gabungan dari Proportionate Stratified Sampling Method dan Snowball Smapling Method. Dimana Proportionate Stratified Sampling Method adalah teknik pengambilan sampel dalam bentuk distrstifikasi secara proposional, namun tidak dipilih acak melainkan secara kebetulan saja. Sedangkan Snowball Smapling Method merupakan cara pengambilan sampel ini adalah dengan mengetahui informasi dari satu atau dua orang sesuai dengan karaktristik atau ciri - ciri yang telah ditentukan menjadi sampel atau responden dalam penelitian ini. Kemudian meminta kepada sampel pertama tersebut untuk menunjukkan orang lain yang kira - kira bisa dijadikan sampel selanjutnya. Sampel dalam penelitian ini diambil menggunakan formula yang dikemukakan oleh Yamane (1973) sebagaimana dikutip Utami dan Supramono (2003) sebagai berikut:

$$
\begin{aligned}
& \mathrm{n}=\frac{N}{N d^{2}+1} \\
& \mathrm{n}=\text { jumlah sampel } \\
& \mathrm{N}=\text { jumlah populasi } \\
& \mathrm{d}=\text { presisi yang ditetapkan sebesar } 10 \%
\end{aligned}
$$

Populasi dalam penelitian ini adalah 532 ibu rumah tangga. Maka sampel yang diperoleh adalah :

$$
\begin{aligned}
& \mathrm{n}=\underline{532} \\
& \quad\left(532 \times 0,1^{2}\right)+1 \\
& =84,1772 \\
& =80
\end{aligned}
$$

Dari 80 sampel yang diperoleh kemudian sampel tersebut dibagi menggunakan metode Proportionate Stratified Sampling Method maka diperoleh sampel sebanyak 40 ibu rumah tangga yang tidak bekerja dan 40 ibu rumah tangga yang bekerja. 
Variabel yang ada dalam penelitian ini adalah literasi keuangan dan alokasi pendapatan yang meliputi konsumsi, tabungan dan investasi. Definisi alokasi pendapatan menurut Masassya (2004:9-10) adalah proses implementasi dari perencanaan keuangan yang telah dibuat dari tiga hal pokok, antara lain:

1. Konsumsi, pengalokasian ini termasuk pengeluaran biaya (fixed cost) yang tidak bisa ditunda lagi, yaitu angsuran rumah, biaya listrik, air, telepon, biaya makan, minum, dan rekreasi. Biaya konsumsi ini beragam, akan tetapi perlu dipatok atau ditentukan lazimnya biaya ini berkisar antara $40 \%-50 \%$.

2. Saving atau tabungan, pengalokasian pada tabungan bisa dimasukkan sebagai simpanan / tabungan tetap dan bisa dimaksudkan sebagai tabungan untuk berjaga - jaga yaitu misalnya ada keperluan ke dokter dan memberi sumbangan. Tabungan ini juga perlu ditentukan dan pada umumnya berkisar 25\% dimana 10\% - 15\% digunakan sebagai motif berjaga - jaga dan sisanya digunakan sebagai tabungan tetap.

3. Investasi, pengalokasian pada investasi dini dimaksudkan sebagai pengembangbiakan uang secara terencana dan disiplin.

Dalam kuesioner ini, terlebih dahulu responden diminta untuk mengisikan presentase jumlah konsumsi, tabungan dan investasi yang dilakukannya.

Sehingga dari rata - rata presentase tersebut, dapat dilihat presentase jumlah alokasi pendapatan ibu rumah tangga yang bekerja dan yang tidak bekerja. Selanjutnya terdapat pertanyaan - pertanyaan mengenai persepsi alokasi pendapatan rumah tangga sejumlah 16 buah. Setiap dimensi faktor akan diukur dengan skala likert, yang merupakan skala ordinal. Ghozali (2001) sebagaimana dikutip oleh Anggaran (2012) membagi skala tersebut menjadi lima tingkat preferensi jawaban sebagai berikut:

$1=$ sangat tidak setuju

2 = tidak setuju 
$3=$ agak setuju

$4=$ setuju

5 = sangat setuju

Semakin tinggi rata - rata skor menunjukkan persepsi alokasi pendapatan yang semakin baik, indicator konsumsi yang baik, tabungan dan investasi yang penting. Semakin baik konsumsi artinya ibu rumah tangga di smaping melakukan penghematan, beliau juga berani membayar untuk harga yang tinggi demi memperoleh kualitas terbaik yang diinginkan.

Sedangkan untuk variabel yang kedua adalah terkait dengan literasi keuangan dimana memiliki definisi sebagai pengetahuan untuk mengelola keuangan dalam pengambilan keputusan keuangan sebagaimana yang dikemukakan oleh Chen dan Volpe (1998). Definisi tersebut dapat dijabarkan ke dalam 4 dimensi yaitu:

1. Manajemen keuangan pribadi (personal finance) merupakan proses perencanaan dan pengendalian keuangan dari unit individu atau keluarga.

2. Bentuk simpanan di Bank yang dapat dilakukan dalam bentuk tabungan (sebagian pendapatan masyarakat yang tidak dibelanjakan disimpan sebagai cadangan guna berjaga - jaga dalam jangka pendek), deposito berjangka (simpanan pada Bank yang penarikannya hanya dapat dilakukan dalam jangka waktu tertentu), sertifikat deposito (deposito berjangka yang bukti simpanannya dapat diperdagangkan) dan giro (simpanan pada bank yang dapat digunakan sebagai alat pembayaran).

3. Asuransi adalah salah satu bentuk pengendalian resiko yang dilakukan dengan cara mengalihkan/ transfer resiko dari satu pihak ke pihak lain (dalam hal ini adalah perusahaan asuransi). Pengertian asuransi yang lain adalah merupakan suatu pelimpahan resiko dari pihak pertama kepada pihak lain.

4. Investasi merupakan suatu bentuk pengalokasian pendapatan yang dilakukan saat ini untuk memperoleh manfaat keuntungan (return) di kemudian hari yang bisa melebihi modal investasi yang dikeluarkan saat ini 
Pertanyaan - pertanyaan mengenai literasi keuangan di kuesioner tersebut berisi 10 pertanyaan berupa pilihan ganda yang terdiri dari 4 komponen yang meliputi pengetahuan pribadi dalam bidang pengetahuan umum, simpanan dan peminjaman dana, asuransi dana dan investasi.

Pengelompokan skor dilakukan dengan menghitung jawaban benar yang dikelompokan ke dalam dua kategori menurut presentase dari seluruh peserta survey. Kategori pertama mencakup skor 0 hingga 50\% (tingkat pengetahuan rendah) dan yang kedua 51 - 100\% (tingkat pengetahuan tinggi).

Teknik analisis data yang digunakan dalam penelitian ini adalah dengan analisis deskriptif, berusaha menjelaskan atau menggambarkan berbagai karakteristik data seperti mean, varians, serta distribusi frekuensi (Situmorang dan Muslich 2010: 10).

Pengumpulan data untuk penelitian ini dilakukan dengan menggunakan studi dokumentasi dengan menggunakan data pendukung melalui studi literatur dan jurnal untuk mendapatkan gambaran masalah yang diteliti.data pendukung diperoleh dari kuisioner tertutup dimana didalam kuisioner tersebut telah disediakan semua aalternatif jawaban yang telah mewakili variabel yang diteliti sehingga responden hanya perlu memilih alternatif jawaban yang sesuai.

\section{ANALISIS DATA}

\section{Karakteristik Responden}

Sebanyak 80 responden yang terdiri dari 40 reponden ibu rumah tangga yang bekerja dan sisanya merupakan ibu rumah tanga yang tidak bekerja telah memenuhi kriteria sebagai sampel dan telah bersedia mengisi daftar pertanyaan atau kuesioner penelitian dengan lengkap sehingga telah memenuhi persyaratan penelitian. Sebelum menguji hipotesis, perlu diketahui karakteristik reponden terlebih dahulu. Karakteristik responden tersebut meliputi usia, tingkat pendidikan, jumlah tanggungan anak, jenis pekerjaan, jumlah penghasilan per bulan, dan 
jumlah penghasilan suami per bulan. Kemudian dari data yang telah terkumpul diolah dan dilakukan analisis frekuensi dalam tabel berikut:

Tabel 1.1

Karakteristik Responden

\begin{tabular}{|c|c|c|c|c|c|c|}
\hline \multicolumn{2}{|l|}{$\begin{array}{c}\text { Karakteristik } \\
\text { Responden }\end{array}$} & \multicolumn{3}{|c|}{$\begin{array}{l}\text { Ibu Rumah } \\
\text { Tangga yang Tidak } \\
\text { Bekerja }\end{array}$} & \multicolumn{2}{|c|}{$\begin{array}{l}\text { Ibu Rumah Tangga } \\
\text { yang Bekerja }\end{array}$} \\
\hline \multicolumn{2}{|l|}{ Usia } & & Jumlah & Presentase & Jumlah & Presentase \\
\hline \multicolumn{2}{|l|}{$25-29$} & 0 & & $0 \%$ & 5 & $12,5 \%$ \\
\hline \multicolumn{2}{|l|}{$30-39$} & 10 & & $25 \%$ & 13 & $32,5 \%$ \\
\hline \multicolumn{2}{|l|}{$40-49$} & 11 & & $27,5 \%$ & 12 & $30,0 \%$ \\
\hline \multicolumn{2}{|l|}{$50-59$} & 18 & & $45 \%$ & 9 & $22,5 \%$ \\
\hline \multicolumn{2}{|l|}{$>59$} & 1 & & $2,5 \%$ & 1 & $2,5 \%$ \\
\hline \multicolumn{2}{|l|}{ Total } & 40 & & $100 \%$ & 40 & $100 \%$ \\
\hline \multicolumn{2}{|l|}{$\begin{array}{l}\text { Tingkat } \\
\text { Pendidikan }\end{array}$} & & Jumlah & Presentase & Jumlah & Presentase \\
\hline \multicolumn{2}{|l|}{$\mathrm{SD}$} & 0 & & $0 \%$ & 0 & $0 \%$ \\
\hline \multicolumn{2}{|l|}{ SMP } & 4 & & $10,0 \%$ & 0 & $0 \%$ \\
\hline \multicolumn{2}{|l|}{ SMA } & 23 & & $57,5 \%$ & 13 & $32,5 \%$ \\
\hline \multicolumn{2}{|l|}{ D3 } & 3 & & $7,5 \%$ & 12 & $30,0 \%$ \\
\hline \multicolumn{2}{|l|}{ S1 } & 10 & & $25 \%$ & 13 & $32,5 \%$ \\
\hline \multicolumn{2}{|l|}{ Lainnya } & 0 & & $0 \%$ & 2 & $5,0 \%$ \\
\hline \multicolumn{2}{|l|}{ Total } & 40 & & $100 \%$ & 40 & $100 \%$ \\
\hline \multicolumn{2}{|c|}{ Tanggungan Anak } & & Jumlah & Presentase & Jumlah & Presentase \\
\hline \multicolumn{2}{|c|}{0} & 5 & & $12,5 \%$ & 9 & $22,5 \%$ \\
\hline \multicolumn{2}{|l|}{1} & 9 & & $22,5 \%$ & 6 & $15,0 \%$ \\
\hline \multicolumn{2}{|l|}{2} & 16 & & $40,0 \%$ & 17 & $42,5 \%$ \\
\hline \multirow{2}{*}{\multicolumn{2}{|c|}{ Total }} & 10 & & $25,0 \%$ & 8 & $20,0 \%$ \\
\hline & & 40 & & $100 \%$ & 40 & $100 \%$ \\
\hline \multicolumn{4}{|c|}{$\begin{array}{l}\text { Penghasilan perPenghasilan Suami } \\
\text { bulan (jutaan) }\end{array}$} & \multicolumn{2}{|c|}{ Pengasilan Istri } & \\
\hline & Jun & lah & Presentase & Jumlah & Presentase & Presentase \\
\hline $\mathrm{Rp} 1$ & 1 & & $2,5 \%$ & 0 & $0 \%$ & 7,5 \\
\hline Rp $1-$ Rp. 2 & 6 & & $15,0 \%$ & 7 & 17,5 & 35,0 \\
\hline $\operatorname{Rp} 2-\operatorname{Rp} 3$ & 5 & & $12,5 \%$ & 9 & $22,5 \%$ & 27,5 \\
\hline Rp 3 - Rp 4 & 14 & & $35,0 \%$ & 8 & $20,0 \%$ & 15,0 \\
\hline$>\operatorname{Rp} 4$ & 14 & & $35,0 \%$ & 16 & $40,0 \%$ & 15,0 \\
\hline Total & 40 & & $100 \%$ & 40 & $100 \%$ & $100 \%$ \\
\hline
\end{tabular}

Sumber : Data Primer Dioalah, 2017 
Berdasarkan tabel hasil pengolahan deskriptif frekuensi di atas dapat diketahui bahwa usia ibu rumah tangga yang dijadikan sebagai sampel penelitian ini adalah antara 25 tahun sampai di atas 59 tahun. Dari rentang usia tersebut, ibu rumah tangga yang tidak bekerja tidak ada yang berada di rentang usia 25-29 tahun. Sedangkan ibu rumah tangga yang bekerja ada sebanyak $12,5 \%$ yang berada di rentang usia 25-59 tahun dari total sampel ibu rumah tangga yang bekerja. Usia tertinggi dalam penelitian ini adalah di atas 59 tahun. Dalam kategori ibu rumah tangga yang tidak bekerja terdapat 1 orang yang berusia di atas 59 tahun yaitu ber usia 62 tahun. Sedangkan untuk kategori ibu rumah tangga yang bekerja terdapat 1 orang yang berusia di atas 59 tahun yakni berusia 61 tahun dan bekerja sebagai wirausahawati.

Tingkat pendidikan yang dimiliki oleh ibu rumah tangga yang tidak bekerja paling rendah adalah tingkat SMP. Jumlah ibu rumah tangga yang tidak bekerja yang memiliki tingkat pendidikan SMP adalah sebanyak 10\% dari 40 sampel. Pendidikan tertingi yang dimiliki oleh ibu rumah tangga yang tidak bekerja adalah tingkat S1. Pada tingkat ini terdapat $25 \%$ dari $40 \mathrm{ibu}$ rumah tangga yang tidak bekerja. Sedangkan untuk ibu rumah tangga yang bekerja tingkat pendidikan paling rendah adalah SMA. Pada tingkat SMA terdapat 32,5\% dari total sampel ibu rumah tangga yang bekerja. Jumlah ini sama dengan ibu rumah tangga yang bekerja yang memiliki tingkat pendidikan S1. Sedangkan untuk tingkat pendidikan lainnya terdapat 2 oang (5\%). Tingkat Pendidikan ini adalah S2 dimana ibu rumah tangga ini bekerja sebagai PNS dan bekerja di perusahaan swasta.

Tanggungan yang diterima ibu rumah tangga berbeda-beda kaitanya dengan jumlah anak yang dimiliki. Ibu rumah tangga yang tidak bekerja yang tidak memiliki tanggungan anak sebanyak 5 orang atau 12,5\% dari jumlah sampel. Sebagian besar ibu rumah tangga yang tidak bekerja memiliki tanggungan anak sejumlah 2 anak yaitu sebanyak $40 \%$ ibu rumah tangga yang tidak bekerja. Di sisi lain, ibu 
rumah tangga yang bekerja yang tidak memiliki tanggungan anak ada sebanyak 9 orang atau 22,5\%. Sebagian besar ibu rumah tangga yang bekerja memiliki tanggunagn anak sebanyak 2 anak. Ibu rumah tangga yang bekerja yang memiliki tanggungan 2 anak adalah sebanyak 17 orang atau sebesar $42,5 \%$.

Selain jumlah tanggungan yang berbeda tentu saja jumlah penghasilan yang diterima ibu rumah tangga juga berbeda tiap individunya. Dari tabel 4.1 di atas dapat diketahui bahwa ibu rumah tangga yang tidak bekerja sebagian besar suaminya berpenghasilan antara Rp.4.000.000 sampai dengan Rp.5.000.000 dan di atas Rp.5.000.000. Ibu rumah tangga yang tidak bekerja yang tingkat penghasilan suami antara Rp.4.000.000 sampai dengan Rp.5.000.000 sebanyak 14 orang atau 35\%. Jumlah ini sama dengan ibu rumah tangga yang tidak bekerja yang memiliki suami dengan tingkat penghasilan di atas Rp.5.000.000. Sedangkan ibu rumah tangga yang bekerja memiliki suami dengan tingkat penghasilan di atas Rp.5.000.000 yaitu sebanyak 16 orang atau $40 \%$.

Tabel 1.2

Karakteristi Pekerjaan Responden

\begin{tabular}{|l|c|c|}
\hline \multicolumn{1}{|c|}{ Pekerjaan } & Jumlah & Presentase \\
\hline PNS & 2 & $5,0 \%$ \\
\hline Swasta & 24 & $60,0 \%$ \\
\hline Wirausahawati & 12 & $30,0 \%$ \\
\hline Lainyna & 2 & $5,0 \%$ \\
\hline \multicolumn{1}{|c|}{ Jumlah } & $\mathbf{4 0}$ & $\mathbf{1 0 0 \%}$ \\
\hline
\end{tabular}

Sumber : Data Primer Diolah, 2017

Berdasarkan tabel 1.2 dapat diketahui bahwa sebagian besar ibu rumah tangga yang dijadikan sampel dalam penelitian ini bekerja sebagai karyawan di perusahaan swasta yaitu sebanyak 24 orang atau $60 \%$. Sedangkan 12 orang atau $30 \%$ bekerja sebagai wirausahawati dan 2 orang 
(5\%) bekerja sebagai PNS. Sisanya sebanyak 2 orang atau 5\% bekerja di sektor lain.

\section{Gambaran Alokasi Pendapatan Ibu Rumah Tangga}

Perbedaan kedua jenis sumber pendapatan rumah tangga yang dimiliki oleh kedua jenis ibu rumah tangga dalam penelitian ini menjadikan dasar dilakukan penelitian mengenai pola alokasi pendapatan antara kedua jenis ibu rumah tangga tersebut. Karena dengan perbedaan peran, keduanya memiliki perlakuan yang berbeda dalam mengalokasikan pendapatan rumah tangganya. Pola alokasi pendapatan dilihat dari rata-rata presentase alokasi pendapatan untuk konsumsi, tabungan, investasi yang biasa dilakukan baik oleh ibu rumah tangga yang tidak bekerja dan ibu rumah tangga yang bekerja, dapat dilihat dalam tabel di bawah ini :

Tabel 1.3

Rata-rata Alokasi Pendapatan Ibu Rumah Tangga

\begin{tabular}{|l|l|l|l|c|}
\hline \multicolumn{1}{|c|}{ Jenis Ibu Rumah Tangga } & \multicolumn{4}{|c|}{ Alokasi Pendapatan } \\
\cline { 2 - 5 } & Konsumsi & Tabungan & \multicolumn{1}{|c|}{ Investasi } & Total \\
\hline Ibu rumah tangga yang tidak bekerja & $69,8 \%$ & $21,6 \%$ & $8,6 \%$ & $100 \%$ \\
\hline Ibu rumah tangga yang bekerja & $60,2 \%$ & $23,6 \%$ & $16,2 \%$ & $100 \%$ \\
\hline
\end{tabular}

Sumber : Data Primer Diolah, 2017

Konsumsi merupakan aspek terbesar dalam pengalokasian ibu rumah tangga yang bekerja maupun tidak. Sebesar 69,8\% alokasi pendapatan ibu rumah tangga yang tidak bekerja terletak pada aspek konsumsi. Begitu pula dengan ibu rumah tangga yang bekerja mengalokasikan sebesar 60,2\% pendapatanya pada aspek konsumsi. Sedangkan aspek pengalokasian pendapatan terbesar kedua adalah aspek tabungan. Sebesar 21,6\% ibu rumah tangga yang tidak bekerja mengalokasikan pendapatnnya untuk tabungan. Sedangkan ibu rumah tangga yang bekerja mengalokasikan pendapatannya sebesar $23,6 \%$ untuk aspek tabungan. Aspek yang ketiga merupakan aspek yang terkecil dalam 
pengalokasian pendapatan baik oleh ibu rumah tangga yang tidak bekerja maupun ibu rumah tangga yang bekerja. Pengalokasian pendapatan yang dialakukan ibu rumah tangga yang tidak bekerja untuk investasi sebesar $8,6 \%$ ssedangkan ibu rumah tangga mengalokasikan sebesar $16,2 \%$ dari pendapatannya untuk investasi baik pada sektor riil maupun non riil.

Sedangkan untuk skor pengalokasian pendapatan baik untuk aspek konsumsi, tabungan dan investasi dapat dilihat pada tabel berikut :

Tabel 1.4

Persepsi Pola Alokasi Pendapatan Ibu Rumah Tangga

\begin{tabular}{|c|c|c|c|}
\hline No & $\begin{array}{c}\text { Persepsi Alokasi Pendapatan Ibu Rumah } \\
\text { Tangga }\end{array}$ & \begin{tabular}{lr|} 
Skor & Ibu \\
Rumah & Tangga \\
yang & Tidak \\
Bekerja & \\
\end{tabular} & \begin{tabular}{|lr} 
Skor & Ibu \\
Rumah & \\
Tangga & Yang \\
Bekerja & \\
\end{tabular} \\
\hline \multicolumn{4}{|c|}{ Persepsi Pola Alokasi Konsumsi } \\
\hline 1 & $\begin{array}{l}\text { Saya membeli barang kebutuhan } \\
\text { sehari-hari untuk pemenuhan gizi }\end{array}$ & 4,05 & 4,23 \\
\hline 2 & $\begin{array}{lcr}\text { Saya selalu } & \text { membeli } & \text { produk } \\
\text { kebutuhan } & \text { sehari-hari } & \text { yang } \\
\text { menawarkan diskon } & & \\
\end{array}$ & 3,20 & 3,30 \\
\hline 3 & $\begin{array}{l}\text { Saya akan cenderung memilih biaya } \\
\text { pendidikan yang murah }\end{array}$ & 2,83 & 2,55 \\
\hline 4 & $\begin{array}{lrr}\text { Dalam } \quad \text { memilih } & \text { produk } \\
\text { pendidikan, } & \text { saya } & \text { selalu } \\
\text { memperhatikan mutu } & \\
\end{array}$ & 4,35 & 4,45 \\
\hline 5 & $\begin{array}{l}\text { Saya membeli pakaian dan aksesoris untuk } \\
\text { mengikuti trend }\end{array}$ & 1,85 & 2,03 \\
\hline 6 & $\begin{array}{l}\text { Saya akan merasa bangga jika } \\
\text { membeli pakaian dan aksesoris yang } \\
\text { bermerek }\end{array}$ & 1,68 & 2,03 \\
\hline 7 & $\begin{array}{l}\text { Saya akan merasa bangga jika pergi ke } \\
\text { tempat hiburan yang berkelas }\end{array}$ & 1,55 & 2,20 \\
\hline 8 & $\begin{array}{l}\text { Saya selalu memperhatikan } \\
\text { kelengkapan fasilitas dan kenyamanan } \\
\text { pada saat pergi ke tempat hiburan }\end{array}$ & 3,55 & 3,55 \\
\hline 9 & $\begin{array}{l}\text { Harga yang lebih murah merupakan } \\
\text { faktor yang sangat penting dalam } \\
\text { menentukan tempat hiburan }\end{array}$ & 2,78 & 2,95 \\
\hline 10 & $\begin{array}{l}\text { Saya cenderung memilih penyedia layanan } \\
\text { kesehatan yang memberikan kesan berkelas }\end{array}$ & 2,38 & 2,60 \\
\hline
\end{tabular}




\begin{tabular}{|c|c|c|c|}
\hline 11 & $\begin{array}{l}\text { Harga merupakan faktor utama yang } \\
\text { menjadi pertimbangan dalam memilih } \\
\text { tempat check- up kesehatan }\end{array}$ & 3,48 & 3,28 \\
\hline 12 & $\begin{array}{l}\text { Saya selalu memperhatikan } \\
\text { kelengkapan fasilitas dan tenaga medis } \\
\text { yang terlatih dalam melakukan check- } \\
\text { up kesehatan }\end{array}$ & 4,18 & 4,13 \\
\hline 13 & $\begin{array}{l}\text { Saya mengalokasikan sekitar } 40 \%- \\
50 \% \text { dari total pendapatan rumah } \\
\text { tangga saya untuk konsumsi }\end{array}$ & 3,25 & 3,35 \\
\hline \multicolumn{4}{|c|}{ Persepsi Pola Alokasi Tabungan } \\
\hline 14 & $\begin{array}{l}\text { Saya menyisihkan } 10 \% \text { hingga } 15 \% \\
\text { dari total pendapatan rumah tangga } \\
\text { saya untuk ditabung }\end{array}$ & 4,00 & 3,98 \\
\hline 15 & $\begin{array}{l}\text { Saya menyisihkan uang dari } \\
\text { sebagian penghasilan untuk motif } \\
\text { berjaga-jaga yang dapat digunakan } \\
\text { sewaktu-waktu }\end{array}$ & 4,23 & 4,20 \\
\hline \multicolumn{4}{|c|}{ Persepsi Pola Alokasi Investasi } \\
\hline 16 & $\begin{array}{l}\text { Saya juga melakukan investasi dengan } \\
\text { tujuan untuk memperoleh keuntungan }\end{array}$ & 3,43 & 3,93 \\
\hline
\end{tabular}

Sumber : Data Primer Diolah, 2017

Persepsi pola alokasi pendpaatan ibu rumah tangga ini dilihat dari semakin tingginya rata-rata skor semakin menunjukkan ibu rumah tangga yang setuju pada pernyataan tersebut. Kemudian jika dilihat dari persepsi dalam mengalokasian pendapatan rumah tangga untuk konsumsi yang dilakukan oleh ibu rumah tangga yang bekerja tidak memiliki perbedaan yang signifikan dibandingkan dengan ibu rumah tangga yang tidak bekerja. Tetapi perbendaan sedikit terlihat lebih banyak pada item pernyataan nomor 5,6 dan 7. Pada nomor item pernyataan tersebut menyebutkan bahwa konsumsi dilakukan untuk mengikuti trend, barang bermerk dan hiburan ke tempat yang berkelas. Ibu rumah tangga yang bekerja dalam tiga hal konsumtif tersebut lebih banyak menggunakan pendapatannya dibandingkan dengan ibu rumah tangga yang tidak bekerja. Hal ini terlihat dari skor untuk ibu rumah tangga yang bekerja pada item pernyataan nomor 5,6 dan 7 lebih tinggi daripada ibu rumah 
tangga yang tidak bekerja. Ibu rumah tangga bersedia untuk mengalokasikan pendapatan yang tidak sedikit demi memeroleh kualitas yang baik untuk priotas kebutuhan primer seperti barang kebutuhan sehari-hari, pendidikan, dan kesehatan. Meskipun beliau tetap mengusahakan untuk bertindak ekonomis seperti mencari diskon.

Rata-rata ibu rumah tangga juga mengalokasikan sekitar 10\% hingga $15 \%$ dari pendapatannya untuk ditabung sebagai motif berjagajaga yang dapat digunakan sewaktu-waktu. Pilihan untuk ditabung sebagai motif berjaga-jaga ini lebih banyak dipilih oleh ibu rumah tangga yang tidak bekerja. Sedangkan untuk investasi dengan motif mencari keuntungan lebih banyak dipilih oleh ibu rumah tangga yang bekerja.

\section{Gambaran Literasi Keuangan Ibu Rumah Tangga}

Tingkat literasi keuangan yang dimiliki oleh ibu rumah tangga baik yang bekerja maupun yang tidak bekerja dapat dilihat dari 4 dimensi literasi keuangan yang terdiri dari pengetahuan umum tentang keuangan pribadi, simpanan dan pinjaman dana, asuransi dana, dan investasi. Dari keempat dimensi literasi keuangan tersebut dapat digunakan untuk mengkategorikan tingkat literasi keuangan yang terbagi atas tingkat literasi keuangan rendah dan tinggi. Dimana kategori rendah berada pada skor 0-50 dan kategori tinggi berada pada rentang skor 51100. Kategori tingkat literasi keuangan ibu rumah tangga dapat dilihat pada tabel berikut:

\section{Tabel 1.5}

Kategori Literasi Keuangan

\begin{tabular}{|l|l|l|l|}
\hline \multicolumn{1}{|c|}{ Jenis Ibu Rumah Tangga } & \multicolumn{3}{|c|}{ Tingkat Literasi Keuangan } \\
\cline { 2 - 4 } & Rendah & \multicolumn{1}{|c|}{ Tinggi } & Jumlah \\
\hline Ibu rumah tangga yang tidak bekerja & 37 & 3 & 40 \\
\hline Ibu rumah tangga yang Bekerja & 28 & 12 & 40 \\
\hline
\end{tabular}

Sumber : Data Primer Diolah, 2017 
Berdasarkan tabel di atas, rata- rata ibu rumah tangga yang tidak bekerja berada pada tingkatan literasi keuangan rendah. Sedangkan ibu rumah tangga yang bekerja lebih banyak yang memiliki tingkat literasi keuangan tinggi. Sehingga dapat dikatakan bahwa tingkat literasi keuangan ibu rumah tangga yang bekerja lebih tinggi dibandingkan ibu rumah tangga yang tidak bekerja.

Perbedaan tingkat literasi keuangan antara ibu rumah tangga yang bekerja dan tidak bekerja terlihat dari jumlah tiap kategori. Kategori literasi keuangan rendah untuk ibu rumah tangga yang tidak bekerja terdapat 37 orang yang masuk kategori ini. Sedangkan sisanya sebanyak 3 orang dari ibu rumah tangga yang tidak bekerja berada pada kategori tingkat literasi keuangan yang tinggi. Untuk ibu rumah tangga yang bekerja yang berada pada kategori tingkat literasi keuangan rendah ada sebanyak 28 orang dimana jumlah ini lebih sedikit dibandingkan dengan ibu rumah tangga yang tidak bekerja. Sedangkan sisanya sebanyak 12 orang berada pada kategori tingkat literasi keuangan tinggi. Jumlah ibu rumah tangga yang berada pada kategori tingkat literasi keuangan tinggi ini lebih banyak dibandingkan jumlah ibu rumah tangga yang tidak bekerja.

\section{Keterkaitan Ibu Rumah Tangga dengan Tingkat Literasi Keuangan dan Alokasi Pendapatan}

Tingkat literasi keuangan ibu rumah tangga yang bekerja yang berada pada kategori tinggi lebih banyak dibandingkan ibu rumah tangga yang tidak bekerja. Meskipun dapat dikatakan bahwa ibu rumah tangga masih memiliki tingkat literasi keuangan yang masih tergolong rendah. Namun dari segi alokasi pendapatannya belum menunjukkan dampak dari tingkat literasi keuangan yang dimilikinya. Oleh karena itu, dengan penelitian ini dapat dilihat secara lebih mendetail keterkaitan ibu rumah tangga yang bekerja dan ibu rumah tangga yang tidak bekerja dengan tingkat literasi dan 
alokasi pendapatan yang dilakukannya seperti pada matriks di bawah ini:

Tabel 1.6

Matriks Keterkaitan Literasi Keuangan dan Alokasi Pendapatan Ibu Rumah Tangga

\begin{tabular}{|l|l|l|l|r|}
\hline \begin{tabular}{c} 
Jenis Ibu \\
\multicolumn{1}{c|}{$\begin{array}{c}\text { Rumah } \\
\text { Tangga }\end{array}$}
\end{tabular} & \multicolumn{2}{c|}{ Rendah } & \multicolumn{2}{c|}{ Tinggi } \\
\cline { 2 - 5 } Ibu rumah & Konsumsi & $70,14 \%$ & Konsumsi & $65,00 \%$ \\
tangga yang & Tabungan & $1,49 \%$ & Tabungan & $23,33 \%$ \\
tidak bekerja & Investasi &, $38 \%$ & Investasi & $11,6 \%$ \\
\hline Ibu rumah & Konsumsi & $59,82 \%$ & Konsumsi & $60,84 \%$ \\
tangga yang & Tabungan & $23,93 \%$ & Tabungan & $23,05 \%$ \\
bekerja & Investasi & $16,25 \%$ & Investasi & $16,11 \%$ \\
\hline
\end{tabular}

Sumber : Data Primer Diolah, 2017

Berdasarkan tabel 1.6 dapat dilihat bahwa ibu rumah tangga yang tidak bekerja yang memiliki tingkat literasi rendah lebih banyak mengalokasikan pendapatannya untuk konsumsi daripada ibu rumah tangga yang tidak bekerja yang memiliki tingkat literasi tinggi. Hal ini berbeda dengan ibu rumah tangga yang bekerja. Ibu rumah tangga yang bekerja dengan tingkat literasi keuangan tinggi lebih banyak mengalokasikan pendapatannya untuk konsumsi daripada ibu rumah tangga yang bekerja dengan tingkat literasi keuangan rendah.

Pada aspek tabungan ibu rumah tangga yang tidak bekerja dengan tingkat literasi keuangan tinggi lebih banyak mengalokasikan pendapatnnya untuk tabungan daripada ibu rumah tangga yang tidak bekerja dengan tingkat literasi rendah. Hal yang sama juga terjadi pada aspek investasi pada jenis ibu rumah tangga yang tidak bekerja. Sedangkan ibu rumah tangga yang bekerja dengan tingkat literasi keuangan tinggi lebih sedikit mengalokasikan pendapatannya untuk tabungan dari pada ibu rumah tangga yang bekerja dengan tingkat literasi keuangan rendah. Hal yang serupa juga terjadi pada pengalokasian pendapatan dalam aspek investasi pada jenis ibu rumah tangga yang bekerja. 


\section{Alokasi Pendapatan Ibu Rumah Tangga yang Tidak Bekerja dan Ibu Rumah Tangga yang Bekerja}

Ibu rumah tangga adalah sesorang yang berperan besar dalam kehidupan rumah tangga. Ibu rumah tangga yang mengatur segala sesuatunya agar kehdupan rumah tangga berjalan dengan selayaknya. Segala sesuatu itu meliputi kebutuhan pokok sampai kebutuhan tersier. Selain itu peran yang sangat penting asalah bagaimana ibu rumah tangga dalam mengelola keuangan rumah tangganya ssehingga dapat digunakan secara efektif dan efisien.

Terkait dengan pedapatan yang diterima ibu rumah tangga yang tidak bekerja maupun bekerja terdapat pola alokasi pendapatan yang digunakan untuk memnuhi kebutuhan baik di masa sekarang maupun persiapan kebutuhan untuk masa depan. Alokasi pendapatan yang paling besar adalah untuk konsumsi. Pola alokasi pendapatan untuk konsumsi dari kedua jenis ibu rumah tangga ini tidak memiliki perbendaan yang signifikan. Kedua jenis ibu rumah tangga ini mengalokasikan sebesar $60 \%$ sampai $70 \%$ untuk konsumsi. Konsumsi ini terdiri dari berbagai jenis kebutuhan seperti makanan, pendidikan, pakaian, hiburan dan lainnya.

Dilihat dari item pertanyaan dalam angket yang disebarkan kepada responden, dapat kita lihat bahwa dalam hal konsumsi ibu rumah tangga yang tidak bekerja maupun yang bekerja memiliki persepsi yang sama dalam pengalokasian pendapatan. Hal ini dapat dilihat dari skor setiap item pertanyaan untuk kedua jenis ibu rumah tangga ini memiliki nilai yang hampir sama. Pemilihan makanan untuk pemenuhan gizi, pendidikan yang bermutu, kesehatan yang baik dan hiburan memiliki skor yang tinggi dalam penelitian ini. Sedangkan untuk pemelihin pakaian bermerk dan tempat hiburan yang berkelas kurang diminati dari kedua jenis ibu rumah tangga ini. Selain itu konsumsi lain yang tidak masuk dalam item pertanyaan dalam kuesioner yang ternyata juga merupakan kegiatan yang rutin dilakukan adalah konsumsi untuk 
menyumbang. Menyumbang dalam masyarakat ini dilakukan untuk membantu tetangga atau saudara yang sedang atau akan memiliki hajatan seperti pernikahan dan menyumbang untuk orang yang sakit.

Perbedaan alokasi pendapatan untuk konsumsi yang tidak signifikan antara ibu rumah tangga yang tidak bekerja maupun yang bekerja ini disebabkan oleh jumlah tanggungan kedua jenis ibu rumah tangga ini hampir sama. Tanggunagn yang dimaksud adalah jumlah anak yang dimiliki. Selain itu perbedaan tingkat pendidikan diantara keduanya juga tidak terlalu menonjol. Rata-rata hampir sama antara ibu rumah tangga yang tidak bekerja maupun yang bekerja dari segi jumlah yang memiliki pendidikan tinggi ataupun rendah.

Pengalokasian pendapatan selain untuk konsumsi adalah untuk menabung dan berinvestasi. Kesadaran menabung dari ibu rumah tangga yang tidak bekerja dan ibu rumah tangga yang bekerja sudah dapat dikatakan cukup tinggi. Sekitar $21 \%$ sampai $23 \%$ dari penghasilan sudah dialokasikan untuk menabung. Tidak ada perbedaan yang signifikan untuk tingkat kesadaran menabung dari kedua jenis ibu rumah tangga ini. Ibu rumah tangga yang tidak bekerja megalokasikan sebesar 21,6\% dari total pendapatan untuk menabung, sedagkan ibu rumah tangga yang bekerja mengalokasikan sebesar $23,6 \%$ dari total pendapatan untuk menabung.

Kesadaran menabung bagi ibu rumah tangga ini dipengaruhi oleh beberapa faktor. Bagi ibu rumah tangga yang tidak bekerja kesadaran untuk menabung dipengaruhi oleh kekhawatiran akan adanya kebutuhan yang tak terduga seperti kebutuhan untuk berobat dan biaya tak terduga lainnya. Selain itu pendapatan yang diterima hanya berasal dari suaminya sehingga ibu rumah tangga yang tidak bekerja merasa perlunya menabung kalau suatu saat terjadi hal-hal yang tidak diinginkan sehingga menghambat sumber pendapatan yang diterimanya. Sedangkan untuk ibu rumah tangga yang bekerja faktor yang medorong untuk menabung selain untuk mempersiapkan kebutuhan yang tak terduga adalah kesadaran 
mereka atas batas usia produktif untuk bekerja. Jadi tabungan mereka dapat digunakan untuk memenuhi kebutuhannya ketika mereka sudah tidak bekerja lagi atau pensiun.

Alokasi pendapatan untuk investasi dari ibu rumah tangga yang tidak bekerja maupun yang bekerja masih dapat dikatakan rendah. Pengalokasian untuk nvestasi hanya memiliki proporsi yang sangat kecil dibanding untuk alokasi konsumsi dan tabungan. Terdapat perbedaan yang cukup signifikan antara ibu rumah tangga yang tidak bekerja dan ibu rumah tangga yang bekerja dalam hal investasi. Ibu rumah tangga yang tidak bekerja hanya mengalokasikan sebesar $8,6 \%$ dari total pendapatan yang diterimanya. Sedangkan ibu rumah tangga yang bekerja mengalokasikan sebesar $16,2 \%$ dari total pendapatan yang dterimanya untuk investasi. Perbedaan yang cukup signifikan ini dipengaruhi oleh wawasan yang dimiliki oleh ibu rumah tangga yang bekerja lebih banyak dibandingkan dengan ibu rumah tangga yang tidak bekerja. Wawasan itu bisa diperoleh dari lingkungan tempat ia bekerja, tema-teman seprofesi maupun teman-teman yang bekerja lainnya.

\section{Tingkat Literasi Keuangan Ibu Rumah Tangga yang Tidak Bekerja dan Ibu Rumah Tangga yang Bekerja}

Tingkat literasi keuangan ibu rumah tangga baik yang tidak bekerja maupun yang bekerja dalam penelitian ini dibedakan menjadi dua yaitu tinggi dan rendah. Perbedaan tingkat literasi keuangan dari ibu rumah tangga yang tidak bekerja dan ibu rumah tangga yang bekerja cukup signifian. Hal ini dilihat dari jumlah ibu rumah tangga yang bekerja yan memiliki tingkat literasi keuangan tinggi lebih banyak dibandingkan dengan ibu rumah tangga yang tidak bekerja. Meskipun secara keseluruhan tingkat literasi keuangan yang dimiliki kedua jenis ibu rumah tangga ini digolongkan rendah.

Perbedaan tingkat literasi keuangan antara ibu rumah tangga yang tidak bekerja dengan ibu rumah tangga yang bekerja dipengaruhi oleh faktor lingkungan dan pengetahuan. Ibu rumah tangga yang 
bekerja memiliki lingkungan yang dikelilingi oleh orang yang aktif mencari penghasilan dan mengembangkan diri sehingga hal ini mampu mempengaruhi pola pikir ibu rumah tangga yang bekerja. Selain itu pengetahuan ataupun wawasan yang diterima ibu rumah tangga yang bekerja lebih luas karena sering berbagi pengalaman dengan orang lain. Kedua hal ini yang mempengaruhi tingkat literaisi keuangan ibu rumah tangga yang bekerja lebih tinggi dibandingkan dengan ibu rumah tangga yang tidak bekerja.

Sedangkan dilihat dari keseluruhan kedua jenis ibu rumah tangga ini memiliki tingkat literasi keuangan yang rendah. Hal ini disebabkan kareana tingkat pendidikan rata-rata ibu rumah tangga disini masih rendah. Hanya sedikit yang memiliki tingkat pendidikan sarjana maupun diploma. Kebanyakan ibu rumah tangga disini memiliki tingka pendidikan SMA. Selain itu kehidupan di desa yang membuat mereka kurang berkembang dalam hal pengetahuan keuangan karena rendahnya mobilitas yang terjadi. Kedua hal ini yang menjadi faktor rendahnya literasi keuangan ibu rumah tangga.

\section{Keterkaitan Ibu Rumah Tangga dengan Tingkat Literasi Keuangan dan Alokasi Pendapatan}

Literasi keuangan memang diperlukan oleh ibu rumah tangga untuk menyusun rencana pengelolaan atau penggunaan pendapatannya dalam kehidupan rumah tangganya. Dari penelitian ini diperoleh hasil bahwa tingkat literasi keuangan yang meliputi pengetahuan umum keuangan, simpanan dan pinjaman, asuransi dan investasi dari ibu rumah tangga di Desa Sidomukti Kecamatan Plaosan Kabupaten Magetan masih rendah. Meskipun demikian dari kedua jenis ibu rumah tangga yaitu ibu rumah tangga yang tidak bekerja dan ibu rumah tangga yang bekerja diperoleh hasil bahwa ibu rumah tangga yang bekerja memiliki tingkat literasi keuangan yang lebih tinggi dibandingkan ibu rumah tangga yang tidak bekerja. 
Keterkaitan antara tingkat literasi keuangan dengan alokasi pendapatan ibu rumah tangga dalam penelitian ini memperoleh hasil bahwa ibu rumah tangga yang tidak bekerja dengan tingkat literasi keuangan rendah lebih banyak mengalokasikan pendapatannya untuk konsumsi dibandingkan dengan ibu rumah tangga yang tidak bekerja dengan tingkat literasi keuangan tinggi. Dengan demikian maka alokasi pendapatan untuk tabungan dan investasi ibu rumah tangga yang tidak bekerja dengan tingkat literasi keuangan rendah lebih sedikit dibandingkan dengan yang memiliki tingkat literasi tinggi. Hal ini disebabkan karena ibu rumah tangga yang tidak bekerja dengan tingkat literasi keuangan yang tinggi lebih memahami tentang bagaimana cara mengelola keuangan yang baik dan lebih memahami keuntungan yang akan didapat melalui tabungan dan investasi.

Hasil yang berbeda diperoleh pada jenis ibu rumah tangga yang bekerja. Penelitian ini memperoleh hasil bahwa ibu rumah tangga yang bekerja dengan tingkat literasi keuangan tinggi lebih banyak mengalokasikan pendapatannya untuk konsumsi dibandingkan dengan ibu rumah tangga yang bekerja dengan tingkat literasi keuangan rendah. Dengan demikian maka alokasi untuk tabungan dan investasi ibu rumah tangga yang bekerja dengan tingkat literasi keuangan tinggi lebih sedikit dibandingkan dengan yang memiliki tingkat literasi keuangan rendah. Hal ini dipengaruhi oleh jumlah pendapatan yang diterima ibu rumah tangga yang bekerja dengan tingkat literasi tinggi tidak lebih banyak atau bahkan lebih sedikit daripada yang memiliki tingkat literasi kuangan rendah sedangkan jumlah tanggungan yang mereka miliki rata-rata sama. Hal ini yang menyebabkan tingkat alokasi pendapatan untuk tabungan dan investasi ibu rumah tangga yang bekerja dengan tingkat literasi tinggi lebih sedikit dibandingkan dengan ibu rumah tangga yang bekerja dengan tingkat literasi rendah. 


\section{KESIMPULAN}

Berdasarkan pengujian dan analisis yang dilakukan dalam penelitian ini, maka dpat disimpulkan :

1. Pola alokasi pendapatan dari ibu rumah tangga yang bekerja maupun tidak bekerja tidak memiliki perbedaan yang signifikan. Kedua jenis ibu rumah tangga ini mengalokasikan sebagian besar pendapatannya untuk konsumsi berikut disusul dengan tabungan dan investasi dengan tingkat alokasi terendah.

2. Tingkat literasi keuangan dengan kategori tinggi lebih banyak dimiliki oleh ibu rumah tangga yang bekerja dibandingkan dengan ibu rumah tangga yang tidak bekerja. Selain itu tingkat literasi keuangan ibu rumah tangga secara keseluruhan masih tergolong rendah.

3. Keterkaitan antara tingkat literasi keuangan dan pola alokasi pendapatan ibu rumah tangga yang tidak bekerja menunjukkan bahwa ibu rumah tangga yang tidak bekerja dengan tingkat literasi tinggi bisa lebih hemat dalam mengalokasikan pendapatannya dibandingkan dengan yang memiliki tingkat literasi keuangan rendah. Sebaliknya untuk ibu rumah tangga yang bekerja dengan tingkat literasi keuangan rendah bisa lebih hemat dalam mengalokasikan pendapatannya dibandingkan dengan yang memiliki tingkat literasi keuangan tinggi.

\section{DAFTAR PUSTAKA}

Birnbaum, Norman. 1971. Toward a Critical Sociology. Oxford University Press. New York. Budianto, Ivana Ngawen. 2006. Perbedaan Alokasi Penggunaan Dana Konsumsi Wanita

Rumah Tangga dan Wanita Karir di Surabaya Timur, Universitas Kristen Petra.

Bryne, A. 2007. Employee Saving and Investment Decisions in Defined Contribution Pension Plans/; Survey Evidence from the U.K. financial Services Review 26 (2007) 
Chen, Hiyang 7 Volpe, Ronal P. 1998. An Analysis of Personal Financial Literacy Among College Students. Financial Services Review 72 (2)

Chen, Hiyang 7 Volpe, Ronal P. 2002. Gender Differences in Personal Financial Literacy Among College Students. Financial Services Review 11 (2002) 289-307

Chen, Hiyang 7 Volpe, Ronal P. 2002. Gender Differences in Personal Financial Literacy Among College Students. Financial Services Review

Dhuwita, Qiqin trisna. 2003. Pengujian Analisis Teknikal dalam Memprediksi Indeks LQ 45 di Bursa Efek Jakarta. Tesis. Universitas Diponegoro. Semarang.

Dorimulu, Primus. 2003. Yang Menabur Yang Menuai. Investor. 81, 9 - 71

Garman, E, Thomas and Raymond E, 1997. Personal Finance. Houghton Mifflin. Boston. Ghozali, Imam. 2001. Aplikasi Analisis Multivariate dengan Program SPSS. Edisi 2. Badan

Penerbit Universitas Diponegoro. Semarang.

Halim, Abdul. 2005. Analisis Investasi. Edisi 2. Salemba Empat. Jakatra.

Hoffman \& Wladis, Lois Norma, 1984, Working Mothers : an Evaluative Review of the Concequences for Wife, Husband, and Child.

Masassya, Evlyn G. 2004. Gramedia. Jakarta.

Muda, K., Antoni, Ahmad. 2003. Cara Cerdas Mengelola Investasi Keluarga.Kamus Lengkap Ekonomi. Gitamedia Press. Jakarat.

Munandar, Utami. 1985. Emansipasi dan Peran Ganda Wanita Indonesia. Universitas Indonesia. Jakarat.

Naibaho, Ernika. 2009. Faktor yang Mempengaruhi Peran Ganda Perempuan. Fakultas Ekonomi dna Bisnis.

Navickas, Mycolas, dkk. 2014. Influences of Financial Literacy on Management or Personal Finances in a young Household. Business: Theory and Practice 15 (1): 32 - 40

Putlia, Nancy, 2009, Persepsi dan Aspek Psikologis dalam Pengambilan Keputusan Hutang (Studi pada Home Industri Tempe di Salatiga), Tesis, Salatiga. 
Rini, Mike, 2006. Solusi Mengelola Keuangan Priibadi, PT Elex Media Komputindo, Jakarta. Senduk, Safir, 2001, Mengelola Keuangan Keluarga, Seri Perencanaan Keuangan Keluarga, PT Elex Media Komputindo, Jakarta.

Sina, Peter Garlans. 2012. Analisis Literasi Ekonomi. Jurnal Ekonomi. Volume 8. Nomor 2.

Oktober 2012.

Sina, Peter Garlans dan Ricky Arnold Nggili. 2012. Apakah Kamu Memiliki Tingkat Literasi Keuangan yang Tinggi.

Situmorang, Syafrizal Helmi dan Mulich Lutfi. 2012. Analisis Data untuk Riset Manajemen dan Bisnis. Edisi 2. Usu Press. Medan.

Sudarsono. 1995. Pengantar Ekonomi Mikro. LP3ES. Jakarta.

Sujarwa. 2001. Polemik Gender Antara Realitas dan Refleksi: Sebuah Kajian Sosiologi Seni Fenomenologi. Pustaka Pelajar; Cet. 1 Edition. Jakarta.

Utami, Intiyas dan Supramono. 2003. Desain Proposal Penelitian Studi Akuntansi dan Keuangan. Fakultas Ekonomi Universitas Kristen Satya Wacana, Salatiga.

Wibawa, HK. 2003. Perencanaan Keuangan Keluarga. Salemba Empat. Jakarta. Widyawati, Irin. 2012. Faktor - Faktor yang Mempengaruhi Literasi Finansial Mahasiswa Fakultas Ekonomika dan Bisnis Universitas Brawijaya. Jurnal Akuntansi dan Pendidikan. Volume 1, Nomor 1. Oktober 2012. 